http://jmscr.igmpublication.org/home/ ISSN (e)-2347-176x ISSN (p) 2455-0450

crossref DOI: https://dx.doi.org/10.18535/jmscr/v7i11.31

\title{
Clinical Study of Prevalence and Incidence of Obesity and its Complications
}

\author{
Authors \\ Dr M.N. Shamala. MD. ${ }^{1}$, Dr S.Senthilnathan. M.D. ${ }^{2^{*}}$ \\ ${ }^{1}$ Assistant Professor, Department of Medicine, Annapoorna Medical, College and Hospital, Salem, \\ 637014, Tamil Nadu, India \\ ${ }^{2}$ Associate Professor, Dept. of Medicine, AMC \& H, Salem, 637014, Tamil Nadu, India \\ *Corresponding Author \\ Dr S.Senthilnathan. M.D. \\ Associate Professor, Dept. of Medicine, AMC \& H, Salem, 637014, Tamil Nadu, India
}

\begin{abstract}
Background: In recent years, there has been a marked change in life-style of south Asian countries caused by economic growth, affluence, urbanization and dietary westernization. Few studies on the prevalence of obesity and its complications in Indian population have been reported. However, there has been scarce literature on study of its prevalence in India with criteria suggested by World Health Organization (WHO) for Asians. Informations on such public Health issues.

Introduction: Obesity, refers to excess body fat, has become an important public health problem. Its prevalence continues to increased worldwide. As the prevalence of obesity increases the burden of its associated co-morbidities. Body fat distribution and its effect on mortality and morbidity is current research topic of interest. Obesity occurs in population groups throughout the world. In recent years there has been a marked changes in life-style of south Asian countries caused by economic growth, affluence, urbanization and dietary westernization. Few studies on the prevalence of obesity, hypertension and diabetes in the Indian population have been reported. However there has been scarce literature on the study of prevalence of Type 2 diabetes and hypertension in over weight and obese in India with criteria suggested by World Health Organization (WHO) for Asians. However, there have been no adequate data regarding obesity and to know the incidence of major complications and comparing with incidence in non-obese patients, complications in India.

Aim Of The Study: 1.To study the cases of obesity in wards and out-patient of Annapoorna Medical College and Hospital, Salem, TamilNadu, India. 2.To study the prevalence and incidence of complications in selected cases of the obesity. 3.To know the incidences of major complications \& minor complications among different types of obesity and non-obesity.

Material and Methods: About 200 randomly selected cases of obesity, obesity with complication and non-obese with major complications selected. Cases are analyzed as per the criteria given by WHO for Indian Standard. Data collected analyzed. Cases for study selected from out-patients and in-patients who are coming to hospital for treatment in AMC\&H, Salem. It is a tertiary hospital situated in a Siragapadi, Salem Dt, TamilNadu, India. Data collected analyzed using statistical method.

Results: Out of 200 cases studied, 100 cases were obesity with gradings and selection were based on criteria from WHO and clinical history and physical findings of disease. According to sex, females 71,71.0\% were more than males29,29\%. Among 100 cases 54,54.0\% were overweight,40,40\%. patients were obese with complications. patients had diabetes $6,6.0 \%$ as major complication. 17,17.0\%,complication hypertension, about4,4.0\% both, 6,6.0\%, 21,21.0\% had other associated complications like cor-pulmonale, osteoarthrosis. ---53.53.0\%patients had associated minor complication like Herina, intertrigo, Varicose vein, hypercholesteromia. According to religion
\end{abstract}


Hindus were predominant, based on dietetic habit more among non vegetarians. Among 100 cases of non obese Females 54,54.0\%,Males-29,29.05\%, According to age group the incidence of major complications Diabetes mellitus, Hypertension was $5^{\text {th }}$ to $6^{\text {th }}$ decade. Females were predominant, but males were predominant when compared to obese in non-obese. complications- 49,49.0\%.were DM. 61,61.0\%. were HT. In obese DM 23,23\%. HT 36, 36\%. DM+HT14,14\%. Most of them were maturity onset obesity, all had history of weight gain in females after early menopause and after delivery and LSCS. Remaining with other major and minor complications. 11,11.0\% were obese without complications. Among non-obese.49,49\% were DM.61,61.0\% were HT. Here HT was more than in obese and DM is also more than in Obese.

Conclusion: Present study concluded that the obesity leads to life threatening hazards like DM, HT, Heart diseases, Strokes and others. Complications if not controlled majority of patients with moderate to severe degree of obesity with long standing history are more prone to develop such complications if not controlled in early stages. Therefore prevention of obesity is most important. Various statergies to prevention of obesity are as follows 1.Education about dangers and problems of over eating and strong selection of food. 2.Physical exercise and activity need to be promised. 3.More of smaller meals than fewer larger meals of similar energy values may be effective. 4.Obese patient should be given help and counselling for the management of underlying mechanism and cause. Obesity is the malady of entire person. To treat it otherwise limits the usefulness of even the most vigorous programs. Along with nutritional both pscychological and behavioral science, technology, along with sound nutrition principles should be directed to prevent as well as control the complete problems of obesity.

Keywords: Obesity, non-obesity, BMI, WHR, Complications, Diabetes-mellitus, Hypertension, CAHD, OA, Hernia, Arthralgia, Varicose-vein, intertrigo, flat foot.

\section{Introduction}

The greatest problem of preventive medicine today is obesity. It is a metabolic disorder of excess weight is closely associated with cardio vascular and renal diseases, diabetes, degenerative arthritis, gout, hypoventilation and gall bladder disease, risk for the patients who needs surgical treatment. The complications and hazards of pregnancy and hazards during child birth are multiplied. Thus the overweight is a physical handicap as well as primary health hazards.

\section{Classification of Body Weight in Adults}

The current most widely used criteria for classifying obesity is the BODY MASS IMDEX (BMI: Body weight in kilograms, Divided by height in meters sqare, Table 1), which ranges from under weight or wasting $\left(<18.5 \mathrm{Kg} / \mathrm{m}^{2}\right)$ to severe or morbid obesity $\left(<=40 \mathrm{Kg} / \mathrm{m}^{2}\right)$. In both clinical and research settings, waist circumference, a measure of abdominal adiposity, has become an increasingly important and discriminating measure of over-weight/obesity.

Abdominal adiposity is thought to be a primarily visceral, metabolically active fat surrounding the organs, and is associated with metabolic dysregulation, predisposing individuals to cardiovascular disease and related conditions.
Asper internationally used guidelines of metabolic syndrome- a cluster of dis-metabolic conditions that predispose individuals to cardiovascular disease of which abdominal adiposity is one component- a waist circumference resulting in increase cardiovascular risk is defined as $>-94 \mathrm{~cm}$ in men and $>-80 \mathrm{cms}$ in women, with different cut points recommended in order reduce an ethnicities (e.g.,>-90 and >-80 cm in men and women) respectively in South Asia.

\section{Material and Method}

Cases for present study were selected from the medical wards and out patients of AMC\&H, Salem during the year 2019 January to 2019 August. The selection of cases was purely selective and criteria for the selection were based on the clinical history and physical findings of disease.

Design of Study: Prospective, Ethical clearance: Certified.

Consent: An informed consent obtained.

Material \& Selection of Subjects: An inclusion and exclusion criteria.

Inclusion Criteria: PT with H/O obesity, HT and other associated complications selected. Newly diagnosed after routine blood tests, RBS report for Diabetics on Treatment, Routine B.P for known 
HT is selected. 100 non-obese cases with hypertension, DM complication selected as control cases.

Age $>20$ years of age.

1. Weight $>20 \%$ of ideal weight or BMI $>$ $23 \mathrm{Kg} / \mathrm{m}^{2}$ or waist $>90 \mathrm{~cm}$ in men and > $80 \mathrm{~cm}$ in women.

\section{Criteria for Overweight and Obesity}

1. Weight > $20 \%$ of ideal bodyweight is overweight and $>30 \%$ is obese.

2. $\mathrm{BMI}>23-24.9$ is overweight and $>25$ is obese.

3. Waist circumference: Men $>90 \mathrm{~cm}$, women $>80 \mathrm{~cm}$.

4. Diagnosis of DM :Diabetes was diagnosed using criteria(WHO)Fasting plasma glucose $>=126 \mathrm{mg} / \mathrm{dL} \quad(7.0$ $\mathrm{mmol} / \mathrm{L}$ )

a. $2 \mathrm{~h}$ plasma glucose $>=200 \mathrm{mg} / \mathrm{dL}(11.1$ $\mathrm{mmol} / \mathrm{L}$ ) during an oral glucose tolerance test using a glucose load of equivalent to $75 \mathrm{~g}$ anhydrous glucose in water

b. Symptoms of diabetes plus random plasma glucose $>=200 \mathrm{mg} / \mathrm{dL}(11.1 \mathrm{mmol} / \mathrm{L})$.

Repeat test was carried out to confirm the diagnosis of DM.

\section{Diagnosis of Hypertension}

The diagnosis of hypertension was made on the basis of Joint National Committee VII (JNC VII) criteria. Blood pressure record was performed in two sittings after $2 \mathrm{~min}$ interval and blood pressure $>=140 / 90 \mathrm{~mm}$ of $\mathrm{Hg}$ was taken as hypertensive.

The following parameters were recorded 1.Personal details, which included name, age, sex, address, economic state and occupation.2.History of any relevant previous illness such as diabetes, hypertension. 3.Anthropometry- Height, weight, waist circumference, hip circumference. BMI and waist: Hip ratio was calculated from the parameters measured. 1.Resting blood pressure in the right arm - sitting position. 3.Electrocardiography - Resting if indicated. 4.Biochemical investigations.
Blood sugar profile assessment, which includes fasting ( $8 \mathrm{~h}$ of fasting) blood sugar, $2 \mathrm{~h}$ postprandial blood sugar or glucose tolerance test if indicated. Repeat test for confirmation of diagnosis of DM.

Lipid profile ( $8 \mathrm{~h}$ of fasting) including total cholestral, triglycerides, low density lipoproteins, high density lipoprotein and very low density lipoprotein. Serum uric acid if indicated. Ultrasonography Abdomen if indicated.

\section{Statistical Analysis}

Descriptive statistical analysis has been carried out in the present study and results on categorical measurements are presented in a number (\%). Chi-square

test has been used to find the significance of study parameters on categorical scale between two or more groups.

Exclusion Criteria: Patients who are very sick. Patients who are not willing for examination.

Data Collection \& Methods: Data collected from OP \& IP IN AMC\&H-Salem.

Sample Size: 200 cases.

Method of Collection of Data: 1.All subjects in study groups were selected without any bias for sex, age, severity of control of obesity and complication. 2.Data will be collected during the pre- tested proforma meeting the objectives of the study. 3.Purpose of study will be explained to subject and informed consent obtained. 4.Subject who will fulfill the inclusion criteria are examined. 5.A detailed H/O obesity, DM, HT taking, BP recording. 6.Height, weight \& BMI calculated using standard formulas.

Analysis: Data collected analyzed for the type of obesity associated complications like DM/ HTN and others by using statistical package.

Period of Study: Six months.

\section{Results}

Among 200 cases studied, 100 cases was obese .Among them $92,92.0 \%$ case was obese with complication. Remaining $10,10.0 \%$ was nocomplication. Remaining 100cases were nonobese with major complication like T2DM, 
hypertension and others. Females were majority $(71,71.0 \%)$ and Males were $(29,29 \%$.), Among non-obese also females were majority $(54,54.0 \%)$ and males were $(46,46.0 \%)$. According to age group in obese was5th and $6^{\text {th }}(37,37.0 .0 \%)$ decade, in non-obese in same age group $(38,38.0 \%)$.

Table I.

Gives the distribution of 100 cases studied according to the age and sex. The youngest subject was 22 years and oldest 80 Years of age. The majority of cases were from fifth to sixth decade of life, forming $(37,37.0 \%)$ and $(38,38.0 \%)$ non-obese of total number of cases studied. There were $(71,71.0 \%)$ Females and (29, $29.0 \%$ ) males in obese and in non-obese, females were $(54,54.0 \%)$, and males $(46,46.0 \%)$

Females were Predominant in both groups.

\section{Group $=$ Obese}

\section{Sex $^{\mathrm{a}}$}

\begin{tabular}{|cl|c|c|}
\hline & & Frequency & Percent \\
\hline \multirow{3}{*}{ Valid } & FEMALE & 71 & 71.0 \\
& MALE & 29 & 29.0 \\
& Total & 100 & 100.0 \\
\hline
\end{tabular}

a. Group = Obese

\section{Group $=$ Non-Obese}

$\operatorname{Sex}^{\mathrm{a}}$

\begin{tabular}{|c|c|c|}
\hline $\begin{array}{l}\text { a. GROUP = NON- } \\
\text { OBESE }\end{array}$ & Frequency & Percent \\
\hline $\begin{array}{ll} & \text { FEMALE } \\
\text { Valid } & \text { MALE } \\
& \text { Total }\end{array}$ & $\begin{array}{c}54 \\
46 \\
100 \\
\end{array}$ & $\begin{array}{c}54.0 \\
46.0 \\
100.0\end{array}$ \\
\hline
\end{tabular}

a. Group $=$ Non-Obese

Table II. Distribution of Cases According to the Age

Table II gives the distribution of 200 cases of obese and non-obese cases Studied according to the age and sex. The majority of cases from the $5^{\text {th }}$ and $6^{\text {th }}$ Decade of life, forming $75,75.0 \%$ of the total of 100 cases of obese and same in non-obese forming $73,73.0 \%$,total of 100 cases,
Group = Obese

Age Group $^{\text {a }}$

\begin{tabular}{|cl|c|c|}
\hline & & Frequency & Percent \\
\hline \multirow{4}{*}{ Valid } & $21-30$ & 3 & 3.0 \\
& $31-40$ & 13 & 13.0 \\
& $41-50$ & 22 & 22.0 \\
& $51-60$ & 37 & 37.0 \\
& $61-70$ & 22 & 22.0 \\
& 7.00 & 1 & 1.0 \\
& 33.00 & 2 & 2.0 \\
& Total & 100 & 100.0 \\
\hline
\end{tabular}

a. Group = Obese

Group = Non-Obese

Age Group $^{\text {a }}$

\begin{tabular}{|c|c|c|c|}
\hline & & Frequency & Percent \\
\hline \multirow{8}{*}{ Valid } & $21-30$ & 1 & 1.0 \\
\hline & $31-40$ & 10 & 10.0 \\
\hline & $41-50$ & 24 & 24.0 \\
\hline & $51-60$ & 38 & 38.0 \\
\hline & $61-70$ & 20 & 20.0 \\
\hline & 7.00 & 6 & 6.0 \\
\hline & 44.00 & 1 & 1.0 \\
\hline & Total & 100 & 100.0 \\
\hline
\end{tabular}

a. Group = Non-Obese

Table III Distribution of Cases According to the Percentage of Obesity

\section{Group $=$ Obese}

Table III. Above shows the distribution of Obesities according to the percentage of BMI (Basal metabolic index) and WHR (Waist to Hip ratio). The percentage of overweight calculated allowing $20 \%$ excess to the ideal weight. All cases were classified into three groups of obesity. According to BMI no .of overweight were $(54,54.0 \%)$, total $60,60.0 \%$., Mild obesity were 21,21.0\%-total $81,18.0 \%$. Moderate obesity were $11,11.0 \%$, total $91,91.0 \%$.severe or gross obesity was $8,8.0 \%$,total of $100 \%$.

\section{Frequency Table}

BMI Group ${ }^{\mathrm{a}}$

\begin{tabular}{|c|c|c|c|}
\hline & & Frequency & Percent \\
\hline Valid & $\begin{array}{l}\text { UNDER WEIGHT } \\
\text { NORMAL WEIGHT } \\
\text { OVER WEIGHT } \\
\text { MILD OBESITY } \\
\text { MODERATE OBESITY } \\
\text { SEVERE OBESITY } \\
\text { Total }\end{array}$ & $\begin{array}{c}1 \\
5 \\
54 \\
21 \\
11 \\
8 \\
100\end{array}$ & $\begin{array}{c}1.0 \\
5.0 \\
54.0 \\
21.0 \\
11.0 \\
8.0 \\
100.0\end{array}$ \\
\hline
\end{tabular}

a. GROUP = OBESE 
According to WHR Classification in our study normal $38,38.0 \%$. Obese $62,62.0 \%$, total $100 \%$

WHR Classification $^{\text {a }}$

\begin{tabular}{|ll|c|c|}
\hline & & Frequency & Percent \\
\hline \multirow{4}{*}{ Valid } & NORMAL & 38 & 38.0 \\
& OBESE & 62 & 62.0 \\
& Total & 100 & 100.0 \\
\hline
\end{tabular}

a. Group = Obese

\section{Group $=$ Non-Obese}

\section{Frequency Table}

According to BMI in non-obese cases of underweight were $5,5.0 \%$, Normal weight $87,87.0 \%$. Over weight

\section{BMI Group $^{\text {a }}$}

\begin{tabular}{|c|c|c|c|}
\hline & & Frequency & Percent \\
\hline Valid & $\begin{array}{l}\text { UNDER WEIGHT } \\
\text { NORMAL WEIGHT } \\
\text { OVER WEIGHT } \\
\text { Total } \\
\quad \text { Total }\end{array}$ & $\begin{array}{c}5 \\
87 \\
8 \\
100 \\
100\end{array}$ & $\begin{array}{c}5.0 \\
87.0 \\
8.0 \\
1000000 \\
7.0 \\
100.0\end{array}$ \\
\hline
\end{tabular}

a. Group = Non-Obese

Table IV: Shows the percentage of incidence of obesity in different religious

Groups in different religious groups.

Among 100 cases 96,96.0\%. were Hindus, 2,2.0\% were Christians, and 2,2.0\% Muslims. Hindus were predominant.

\section{Group $=$ Obese}

\section{Religion $^{\mathrm{a}}$}

\begin{tabular}{|cl|c|c|}
\hline & & Frequency & Percent \\
\hline \multirow{4}{*}{ Valid } & Christian & 2 & 2.0 \\
& HINDU & 96 & 96.0 \\
& Muslim & 2 & 2.0 \\
& Total & 100 & 100.0 \\
\hline
\end{tabular}

a. Group = Obese

\section{Group $=$ Non-Obese}

In non-obese group Hindus 95.95.0\%, Followed

By Christians 4,4.0\% and

Muslims $1,1.0 \%$. total of $100 \%$

Religion $^{\text {a }}$

\begin{tabular}{|cl|c|c|}
\hline Religion & & Frequency & Percent \\
\hline \multirow{4}{*}{ Valid } & Christian & 4 & 4.0 \\
& HINDU & 95 & 95.0 \\
& Muslim & 1 & 1.0 \\
& Total & 100 & 100.0 \\
\hline
\end{tabular}

a. Group $=$ Non-Obese
Table V GROUP* MENstual HIS Cross tabulation

\begin{tabular}{|lll|c|c|c|}
\hline & & & \multicolumn{2}{|c|}{ MENUHIS } & \multirow{2}{*}{ Total } \\
\cline { 3 - 5 } & & & Irregular & Regular & \\
\hline \multirow{2}{*}{ GROU } & OBESE & Count & 71 & 29 & 100 \\
$\mathrm{P}$ & & $\%$ within GROUP & $71.0 \%$ & $29.0 \%$ & $100.0 \%$ \\
& NON- & Count & 15 & 85 & 100 \\
& OBESE & \% within GROUP & $15.0 \%$ & $85.0 \%$ & $100.0 \%$ \\
\multirow{2}{*}{ Total } & & Count & 86 & 114 & 200 \\
& & $\%$ within GROUP & $43.0 \%$ & $57.0 \%$ & $100.0 \%$ \\
\hline
\end{tabular}

Table. V shows about $86,43.0 .0 \%$, females, out of 200 cases h/o irregular periods with early and maturity onset of obesity. and $114,57.0 \%$. out of 200 gave h/o regular menstrual cycle. In obese $71,71.0 \%$ and $15,15.0 \% \mathrm{~h} / \mathrm{o}$ irregular periods, obese were predominant. in non-obese $85,85.0 \%$ regular period, here non-obese were predominant.

\section{Chi-Square Tests}

a. 0 cells $(0.0 \%)$ have expected count less than 5 . The minimum expected count is 43.00 .

b. Computed only for a $2 \times 2$ table

Hindus were predominant. Followed by Christians and Muslims. HINDUS

Are majority in areas Surrounding siragapadI salem DT.

Table VI: Distribution of Cases According to the Diet

According to food habits, among obese $90,90.0 \%$ were non-veg (mixed

Diet.10, $10.0 \%$ were vegetarians.

\section{Crosstabs}

\section{GROUP * Diet Cross tabulation}

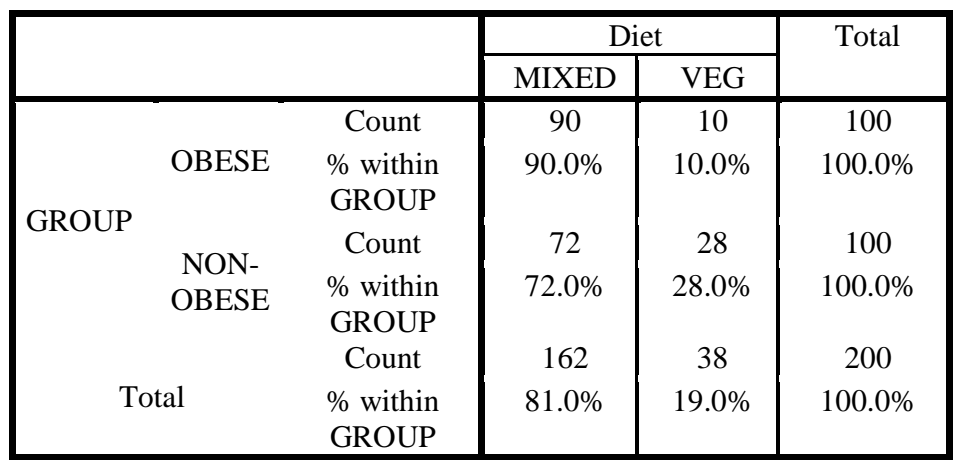

Table VI shows $90,90.0 \%$ obese group were nonvegetarians, and72,72.0\% non-obese, Among nonobese $38,38.0$ were vegetarians 
Table VI: Shows the incidence of obesity in group with different dietetic habit.

About $81,81.0 \%$ people are middle classes and non- vegetarian's majority of them-Growing sheeps, chickens, ducks, cows and pigs. During local village festivals mainly non-vege is main preparations.

Table V: Distribution of Cases According to Types of Obesity:

Group = Obese

GEL Obese $^{\mathrm{a}}$

\begin{tabular}{|cl|c|c|}
\hline & Frequency & Percent \\
\hline \multirow{4}{*}{ Valid } & 15 & 15.0 \\
& Early age obese & 12 & 12.0 \\
& Gradually obese & 37 & 37.0 \\
& Later age obese & 36 & 36.0 \\
& Total & 100 & 100.0 \\
\hline
\end{tabular}

a. GROUP = OBESE shows early- obese $12,12.0 \%$, gradual- obese 37

Gradual-onset obesity predominant, followed by late -onset.

\section{Group = Non-Obese}

Gel Obese $^{\text {a }}$

\begin{tabular}{|l|c|c|}
\hline & Frequency & Percent \\
\hline Valid & 100 & 100.0 \\
\hline
\end{tabular}

a. GROUP $=$ NON-OBESE

\section{Table VII Frequency Table}

BMI Group ${ }^{a}$

\begin{tabular}{|cl|c|c|}
\hline & Frequency & Percent \\
\hline \multirow{6}{*}{ Valid } & UNDER WEIGHT & 1 & 1.0 \\
& NORMAL WEIGHT & 5 & 5.0 \\
& OVER WEIGHT & 54 & 54.0 \\
& MILD OBESITY & 21 & 21.0 \\
& MODERATE OBESITY & 11 & 11.0 \\
& SEVERE OBESITY & 8 & 8.0 \\
Total & 100 & 100.0 \\
\hline
\end{tabular}

a. GROUP = OBESE

Table VII. shows types of obesity .over weight$54,54.0 \%$, Mild obesity-21,21.0\%,Moderate obesity-11,11.0\%, severe obesity-8,8.0\%,Mild obesity more than moderate followed by severe.

Table VIII WHR Classification ${ }^{\mathrm{a}}$

\begin{tabular}{|cc|c|c|}
\hline & & Frequency & Percent \\
\hline \multirow{4}{*}{ Valid } & NORMAL & 38 & 38.0 \\
& OBESE & 62 & 62.0 \\
& Total & 100 & 100.0 \\
\hline
\end{tabular}

a. GROUP $=$ OBESE
According to WHR (Waist to Hip Ratio 38,38.0\% Normal, 62,62.0\%- Obese, Obese were Predominant in our study.

Group = Non-Obese

Frequency Table

BMI Group ${ }^{a}$

\begin{tabular}{|ll|c|c|}
\hline & & Frequency & Percent \\
\hline \multirow{4}{*}{ Valid } & UNDER WEIGHT & 5 & 5.0 \\
& NORMAL WEIGHT & 87 & 87.0 \\
& OVER WEIGHT & 1 & 1.0 \\
& Total & 93 & 93.0 \\
Missing & System & 7 & 7.0 \\
Total & & 100 & 100.0 \\
\hline
\end{tabular}

a. GROUP $=$ NON-OBESE

In non obese underweight 5, 5.0\%, Normal weight- $87,87.0 \%$.

Table IX: Distribution of Cases According to Com

Complications

\section{Group = Obese}

\section{Frequency Table}

DM $^{\mathbf{a}}$

\begin{tabular}{|cc|c|c|}
\hline & & Frequency & Percent \\
\hline \multirow{4}{*}{ Valid } & DIABETES MELLITUS & 8 & 8.0 \\
& NON DM & 77 & 77.0 \\
& T2 DM & 1 & 1.0 \\
& T2DM & 14 & 14.0 \\
& Total & 100 & 100.0 \\
\hline
\end{tabular}

a. GROUP $=$ OBESE

Table IX Shows frequency of major complications in 100 cases of obesity

Diabetes mellitus 19, 19.0\%. non-DM 77.77.0\% HT $^{\mathrm{a}}$

\begin{tabular}{|ll|c|c|}
\hline & & Frequency & Percent \\
\hline Valid & HT & 28 & 28.0 \\
& NON HT & 64 & 64.0 \\
& SHT & 8 & 8.0 \\
& Total & 100 & 100.0 \\
\hline
\end{tabular}

Complication hypertension in 100 cases of obesity. Hypertention-28,28.0\%, SHT- 8, 8.0\%, Non- HT 64,64.0\% 
Group = Obese

Table X

COMP2 $^{\mathrm{a}}$

DM $^{\mathrm{a}}$

\begin{tabular}{|ll|c|c|}
\hline & & Frequency & Percent \\
\hline \multirow{4}{*}{ Valid } & DIABETES MELLITUS & 35 & 35.0 \\
& NON DM & 51 & 51.0 \\
& T2DM & 14 & 14.0 \\
& Total & 100 & 100.0 \\
\hline
\end{tabular}

a. GROUP $=$ NON-OBESE

Frequency of DM in Non Obese 100 Cases. DM$36,36.0 \%$, T2DM 14,14.0\%,NON-DM 51,51.0\%

\section{HT $^{\text {a }}$}

\begin{tabular}{|cc|c|c|}
\hline & & Frequency & Percent \\
\hline \multirow{4}{*}{ Valid } & HT & 37 & 37.0 \\
& NON HT & 39 & 39.0 \\
& SHT & 24 & 24.0 \\
& Total & 100 & 100.0 \\
\hline
\end{tabular}

a. Group $=$ Non-Obese

Hypertension in 100 Cases of Non Obese HT 37, $37.0 \%$, SHT-24, 24.0\%, NON-HT39.39.0\%

HT cases more than SHT.

\section{COMP4}

\begin{tabular}{|c|c|c|}
\hline & Frequency & Percent \\
\hline & 68 & 68.0 \\
anaemia & 1 & 1.0 \\
Anaemia & 6 & 6.0 \\
APD & 5 & 5.0 \\
Artralgia & 1 & 1.0 \\
BA & 1 & 1.0 \\
CAD & 2 & 2.0 \\
CCF & 1 & 1.0 \\
Chr.Bronchitis & 1 & 1.0 \\
COPD & 2 & 2.0 \\
DKA & 1 & 1.0 \\
Hemipaeresis & 1 & 1.0 \\
Hyp-lip & 1 & 1.0 \\
hyp.lip & 1 & 1.0 \\
Hypothy & 1 & 1.0 \\
LRI & 1 & 1.0 \\
OA & 1 & 1.0 \\
Old.PT & 1 & 1.0 \\
PT & 1 & 1.0 \\
RF & 2 & 2.0 \\
V.fever & 1 & 1.0 \\
Total & 100 & 100.0 \\
\hline
\end{tabular}

Complications

1.No of cases

2.Diabetes

3.Hypertention

4.Diabetes + Hypertension

5. Osteo Arthrosis

6.cor-pulmonale

Minor complications

a.Anaemia

b.Hernia

c.Intertrigo

d.Varicose vein

e.flat foot

f.CAD

g.periphe. neuropathy

h.hypercholesterolemia

i.neuritis

j.copd

k.BA

L.gangrene

m.depression

n.CVA,hemiplegia

o.APD

Table XI: Shows the distribution of cases according to complications. Among 100 cases 8, $8.0 \%$ patients who were normal without any

1

$\begin{array}{cccr}\text { obese } & \% & \text { non-obese } & \% \\ 100 & 100 \% & 100 & 100 \% \\ 23 & 23.0 \% & 18 & 18.0 \% \\ 36 & 36.05 \% & 31 & 31.0 \% \\ 20 & 20.0 \% & 25 & 25.0 \% \\ 21 & 21.0 \% & 2 & 2.0 \% \\ 3 & 1.0 \% & 0 & \end{array}$

$11-13$

1

0

1

0

$7-9$

6

9

0

1

1

2

3

$11-11$

complications. Among the -patients 21, 21.0\% were mildly obese. $11,11.0 \%$ were moderately obese. 


\section{JMSCR Vol||07||Issue||11||Page 184-193||November}

23,23.0 \% patients had Diabetes mellitus. All were moderately obese. $36,36.0 \%$ patient Were Hypertensive and $17,17.0 \%$ patients had both Diabetes and Hypertension. Other patients osteoarthrosis, 2,2.0\% had cor-pulmonale and osteoarthrosis 21,21.0\%and Failure, who were Grossly obese. Among the Diabetics 3,3.0\% patients had intertrigo and fungal infection and they were moderately obese. Along with above major complications $5,5.0 \%$ patients had minor complications like Artharlgia, Varicose-vein, hernia and flat foot.

\section{Crosstabs}

[DataSet1]

C:IUsers\USER\Desktop\OBESITY\obesity corrected data.sav

\section{BMI GROUP * DM Cross tabulation}

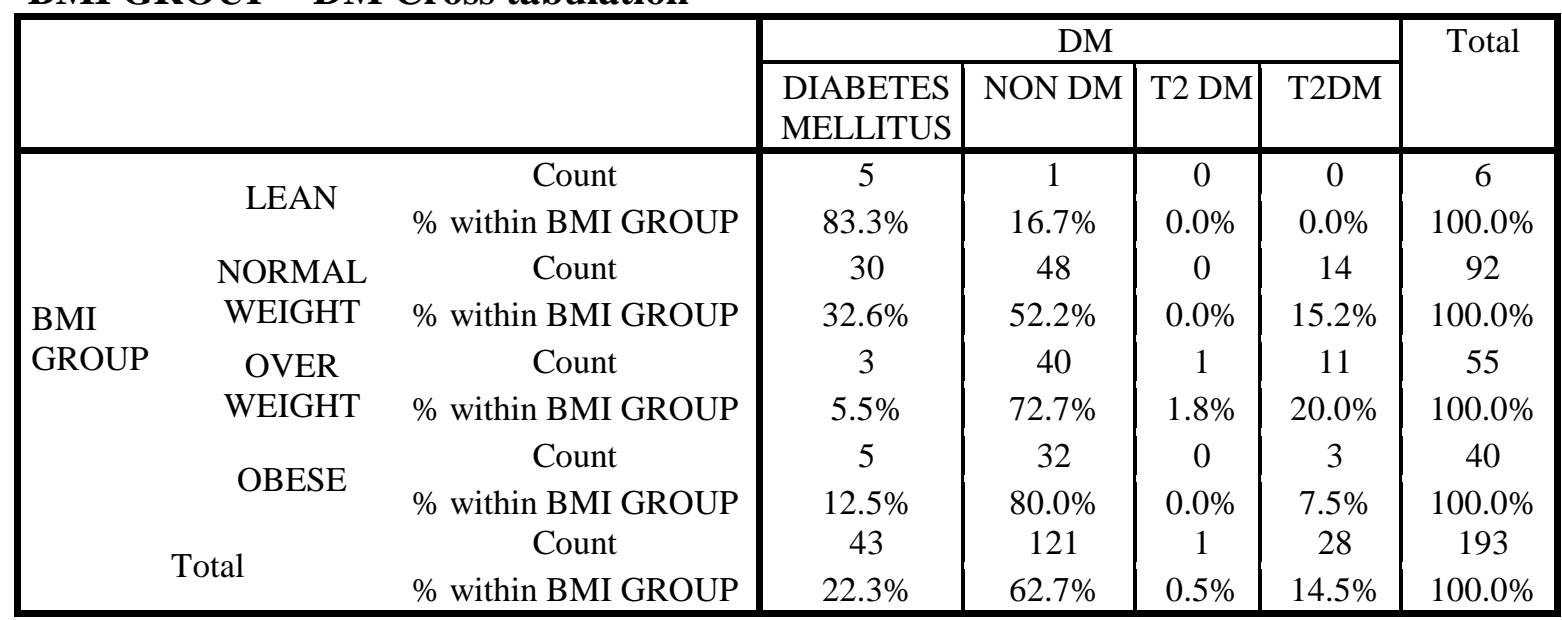

Table XI-5 shows Frequency of DM in Obese and Non-Obese; Lean-5 cases no DM, Normal Weight-14, $14.0 \%, 12,12.0 \%$, Over Weight-3,3.0\%, Obese-29,29.05, DM were More in Obese.

\section{BMI GROUP * HT Cross tabulation}

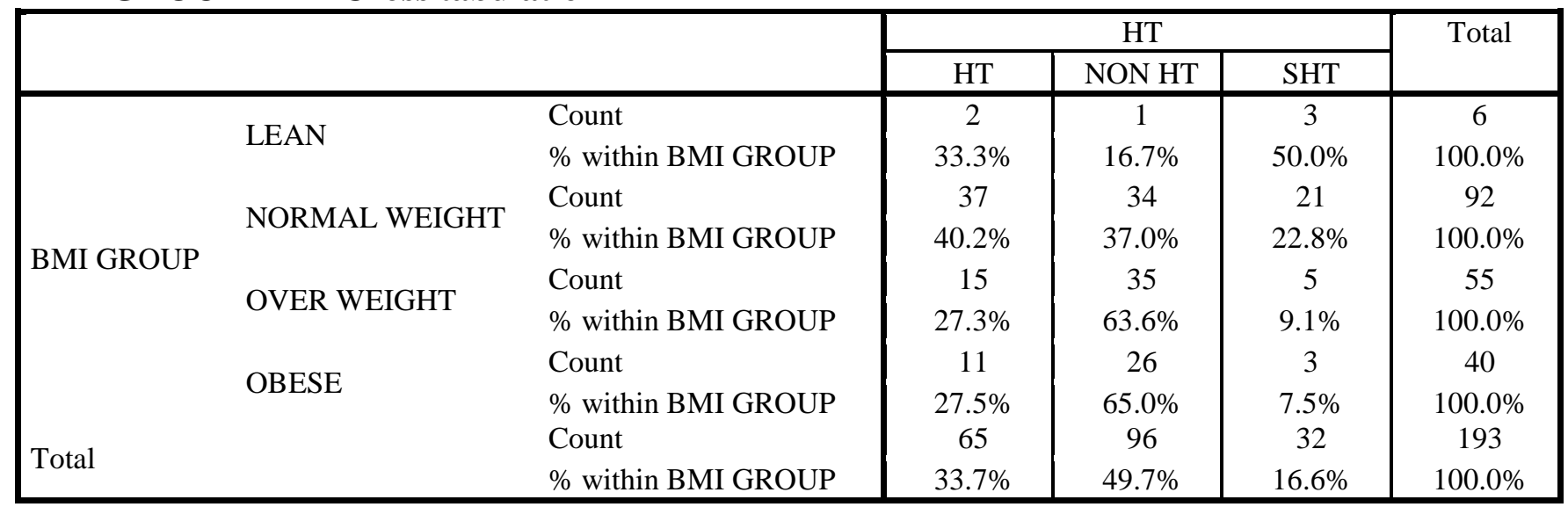

In 200 Cases of Obese and Non-Obese, Frequency of Hypertension, Lean 5,5.0\% HT/SHT, Normal Weight-58, 58.0\%, Over Weight-55, 55.0\%, Obese-95, 95\%,More In Obese Pts

\section{Discussion}

This study was a prospective study, crosssectional study of a selected cases that presented to tertiary care hospital Annapoorna Medical College and Hospital, Siragapadi, Salem Dt, Tamil Nadu, India. 200 Cases Were Selected from In-Patients and Out-Patient Attending. 200 cases selected, 100 cases were Obese and 100 cases were Non-Obese Obese Cases Were Selected as per the WHO Criteria studied for types of obesity, grading, frequency of complications, and 
comparing with non-obese case by statistical analysis. In our study 200caseselected according to sex analysis, females were $71,71.0 \%$ Obese, $54,54.0 \%$ Non-obese. Females were predominant. Males in Obese were 29,29.0\%, non-obese $46,46.0 \%$.males were predominant in non-obese, According to age groups in obese youngest was 22 yrs eldest were 80 yrs, and obesity were more in $5^{\text {th }}$ to $6^{\text {th }}$ decade, in non-obese youngest were 20 yrs and eldest were 82 yrs and major complications were more at the age groups5th to $6^{\text {th }}$ decade. According to economic status in obese there were $28,28.0 \%$, house wives. 10 were not working, drivers2, tailors 2, formers 8, coolys 35 , daily wages 6 .among these obesity was common in house wives, next those not working and on rest, followed by Drivers, tailors and farmers. Most of them were lower middle and poor class were few. Among non-obese 48, were house wives, 30 were coolies were 11, and daily ages 11 , remaining others. according to \%age of obesity over weight $54,54.0 \%$, mild obesity $21,21.05$ moderate obesity $11,11.0 \%$ severe obesity $8,8.0 \%$,in non obsess Under weight$5,5.0 \%$, normal weight $87,87.0 \%$, over weight$8,8.0 \%$. According to WHR (Waist hip ratio) ;normal-38,38.0\%. obese 62,62.0\%. According to religions in obese Hindus were $96,96.0 \%$ and were predominant, followed by christians $2,2.0 \%$, and muslims 2,2.0\%.non-obese HIndus 98,98.0\%, predominant. Christians 4,4.0\%, Muslims$1,1.0 \%$. In females obese, non-obese according to menstrual history 86 had regular and 114 irregular cycles.

\section{Conclusion}

The prevalence of type $2 \mathrm{DM}$, hypertension in the obese group of the study population were found to be $20.2 \%, 22.2 \%$ and in the overweight population were $21,21.0 \% .5 \%$ and $54,54.0 \%$ over weight respectively. This indicates that the prevalence of type 2DM and hypertension increases with increasing weight of the individuals. The prevalence of type $2 \mathrm{DM}$ and hypertension were relatively higher compared with other studies. as obesity Increase the articular joint mainly knee-joint affected. In our study OA $21,21.0 \%$ in obese and2, $2.0 \%$ in non obese. Anaemia 11, 11.0\% in obese and 13,13.0\% in non obese. CAD 7, 7.0 IN obese and 9,9.0\% in non obese.

Conflict of Interest: Nil.

Financial Support: Nil.

\section{References}

1. OBESITY IN INDIA: The weight of the nation; Sanjay Kalra ,AG Unnikrishnan; Journal of medical nutrition And Nutraceuticals (1), 37,2012

2. Is over-weight and OBESITY associated with high frequency Of co- morbid conditions? Snnykumar, Nabiha Mujahidfaruq Amna Aamir, Kailashkumar, Maesajaffer, Pakisthan Journal of rehabilitation 1(2)2012

3. Preventing obesity in India: weighing the otions: Ambikagopalakrishnan, Sanjay Kaira: MK Garge: Indion Journal of endocrinalogy and metabolism 16(1),4,2012

4. World health organization Obesity: Preventing and managing. The global epidemic. Report OF WHO Consultation. World Health World Health organ Tech Repser.2009;894;[Pub Med]

5. Rising burden of obesity in asia: Ambadyramachandran, Chamukuttn Snehalatha; Journal of obesity2010,2010.

6. Haslam D. Obesity:A medical history.obes Rev 2007:8(suppl-1) 31-6 [pubMed]

7. Gelber RP, Gaziana, JM, Manson JE, Buring JE, Sesso HD, A prospective study of body mass index and the risk of developing hypertension in men.AMJ hypertens.2007;20;370-7[PMC Free Article] [Pub Med]

8. Prevalence of obesity, physical inactivity and under nuitrition, a triple burden of disease during transition in developing 
economy. Ram B singh, denial pella, viola Mechirova, Kumar Karthikey Fabien Deemester, Rukam S:Acta cardiology 62(2), 119.127,2017

9. Mohan v, Deepa R.OBESITY\& Abdominal obesity in asian Indians $\mathbf{J}$ Med Res. 2006:123;593-6[pub Med;]

10. Gregg EW, Cheng yj, cadwell BL, imperatore G, WILLIAMS DE, Flegalkmetal, secular trends in cardiovascular disease risk factor according to body mass index in US adults, jama.2005;293;1868-74[pub Med]

11. Reddy KS, Shas B,VARGESS C, Ram doss a. chronic diseases 3. Lancet. 2005;366;17446-57.

12. MPHser,2000:894:i-xii[pub Med]

13. James WPT, Jakson-Leah R , Ni Mhurchuc, Kalamara E, SHAYEGHI M, Rigby

14. World Health organization (WHO) Obesity preventing and managing the global epidemic. Report of WHO consultation(1-253).World health organ Tech Res NJ,et al

15. Flegal KM. Kit, BK, Orpana H .Association of all-cause mortality with overweight and obesity (High Body mass index) in: EZZATIM, Lopez AD, Rodgers A, Murray CJL, editors. Comparitive qualification of health risks: global and regional burden of disease Attributable to selected major risk factors. 1.Geneva : world health organisation:2004.pp.497596

16. Huang Z, willt WC, Manson JE, Rosner B,Stampfer MJ, Spizer FE, et al. Body weight, change and risk for hypertension in women, Ann Intern Med. 1998:128:81.8 [Pub-Med]

17. Wannamethee $\mathrm{Sg}$, shaper AG, Weight change and duration of over- weight and obesity in the incidence of type 2 diabetes care 1999:222; 1266-72 [Pub Med]. 